\title{
Effectiveness of supply chain orientation in container ports: liners' perspective
}

\author{
Sang-Yoon Lee ${ }^{*}$ and Yong-Hee Kim ${ }^{* *}$
}

\begin{abstract}
This paper employs the concept of supply chain orientation in container port management and empirically tests whether the measurement models proposed in some notable previous research have universal application. In addition, this study attempts to identify any significant causal relationships between port supply chain orientation and port performance from the view point of shipping companies. In the current study port supply chain orientation was found to have limited effect on customer satisfaction and port competitiveness, which might has been caused by some implemental and practical issues. However, the present study reveals the potential importance of port supply chain management by empirically demonstrating that "closer relationship with shipping lines" and "innovative value added service" could function as critical components for container ports/terminals to improve customer satisfaction and enhance their competitiveness.
\end{abstract}

Keywords: Port, Container Terminal, Supply Chain Orientation, Measurement Model, Structural Model

\section{Introduction}

It has been noticed that ports are an integral part within a global supply chain as a result of the globalization of production and distribution (Robinson, 2002; Carbone et al., 2003; Bichou and Gray, 2004; Notteboom and Rodrigue, 2005). This suggests that ports should facilitate the

${ }^{*}$ Corresponding Author, Assistant Professor, Graduate School of Logistics/Asia Pacific School of Logistics, Inha University 253 Yonghyun-dong, Nam-gu, Incheon 402-751, Korea. Tel.: +82-32-860-8236, Fax: +82-32-860-8226, Email: sylee@inha.ac.kr

${ }^{* *}$ Graduate Student, Graduate School of Logistics, Inha University 253 Yonghyun-dong, Nam-gu, Incheon 402-751, Korea. Email: yong7022@hotmail.com 
efficiency and effectiveness of their respective supply chains. As a result, it is required for the ports to be oriented towards supply chains to meet the demands and needs of their users and chain partners in more collaborative manners.

The present research employs the concept of supply chain orientation (hereafter SCO) initially proposed by Mentzer et al. (2001), adopted into sea port dimension by Panayides and Song (2006; 2007) and empirically tests whether the measurement model of port supply chain orientation possesses universal application. This paper contributes to Maritime and Port Literature by encompassing diverse container terminals located in Asia, America and Europe, and measuring the degrees of their supply chain orientation from the perspectives of shipping lines as the major customer of port services. Therefore, the current study provides a more balanced view for the supply chain orientation in container ports compared with a few existing literature dealing with supply chain orientation issues in sea ports. In addition, this study attempts to reveal any significant relationship among the port supply chain orientation, customer satisfaction and port competitiveness using valid constructs and indicators tested through a rigorous theoretical process, which may shed more light on the role of supply chain orientation in practice.

This paper is organized as follows: Section 2 reviews the literature on ports as a part of the global supply chain from the theoretical and empirical perspective; Section 3 discusses the theoretical framework; Section 4 outlines the methodology and main findings; the final section presents a conclusion with strategic implications.

\section{Literature review}

The development of global supply chains compels ports roles towards a more efficient distribution of products across the supply chains as well as superior performance in loading and unloading of ships and berth availability. In this new role, the port is considered as part of a cluster of organizations in which different logistics players are involved in bringing value to the final consumers. In order to be successful, such channels need to achieve a higher degree of cooperation and coordination (De Souza et al., 2003; Song and Panayides, 2007).

Mentzer et al. (2001) classified the definitions of supply chain management (hereafter SCM) into three categories: a management philosophy, the implementation of a management philosophy, and a set of management processes. The authors emphasized the importance of embracing the supply chain management philosophy within a firm and called it supply chain orientation (SCO). SCO can be seen as an implementation of SCM philosophy in individual firms in a supply chain while SCM is the total of all the overt management actions performed to implement the SCM philosophy across firms within the supply chain. From this perspective the concept of port supply chain orientation can be understood as the implementation of the collaboration philosophy at the ports in the global trans-ocean supply chains.

Some previous studies have established the relevance of port supply chain orientation and illustrated its strategic implications on ports performance (Robinson, 2002; Paixao and Marlow, 2003; Marlow and Paixao, 2003; Carbone and De Martino, 2003; Bichou and Gray, 2004; 
Notteboom and Rodrigue, 2005; and Panayides and Song, 2006). Although the current literature recognizes the importance of supply chain management for ports and terminals, there is little empirical work on this issue except for a few current studies. Carbone and De Martino (2003) empirically investigated the contribution of the Port of Le Havre to value creation in an automobile supply chain. Panayides and Song $(2006 ; 2007)$ have attempted to develop a measurement instrument that can be used to measure the extent to which a port or container terminal is supply chain oriented. The authors made an empirical investigation on the relationship between supply chain orientation and port performance based on their survey to 32 container terminal operators and made a tentative conclusion that there is a positive relationship between supply chain orientation and performance.

In spite of their pioneering work of measuring the relationship, their findings could not provide comprehensive understanding about port supply chain orientation strategy and its effectiveness due to the lack of balanced views between service providers and actual service users. This point is critical because port supply chain management should encompass various maritime and port supply chain participants and can be more precisely evaluated by their customers. As mentioned, this paper attempts to measure the degrees of supply chain orientation in various container ports over the world from the perspective of shipping lines, which might overcome the weaknesses of existing empirical literature.

\section{Theoretical framework}

\subsection{Research hypothesis}

As defined in previous sections, the current study is aiming to examine the relationships between port supply chain orientation, customer satisfaction and port competitiveness. These relationships can be formulated more clearly by the following three hypotheses.

- Hypothesis 1: Port supply chain orientation has a positive influence on customer satisfaction.

- Hypothesis 2: Port Supply chain orientation exerts a positive influence on port competitiveness.

- Hypothesis 3: Customer satisfaction has a positive influence on port competitiveness

The following discussions are for the latent constructs and measurements employed by the present study to empirically test the proposed three hypotheses.

\subsection{Constructs and measurements}

As explained in the introduction, the current research employs port supply chain orientation constructs and measurements developed by Panayides and Song (2006; 2007). The authors have suggested 20 measurements categorized into four constructs, which are 'relationship with users (RWU)', 'value-added services (VAS)', 'inter-connecting inter-modal infrastructure (ITM)' and 
'channel integration practices (CIP)' as shown in table 1. The rationale of the constructs and measures advocated by the authors can be summarized as follows.

\section{Relationship with users (RWU)}

Kalwani and Narayandas (1995) have asserted the importance of establishing long-term cooperative relationships in supply chain by postulating that supplier firms in long-term relationships with select customers are able to retain or even improve their profitability levels more than firms that employ a transactional approach. In the logistics industry, the development of a long-term collaboration between users and service providers has been viewed as a strategic choice rather than the transactional type of collaboration (Doney and Cannon, 1997). This is also a critical component for future business success and the attainment of competitive advantage. In order to achieve intermodal operational synchronization, it is essential for ports to have an appropriate governance structure in the relationship with shipping lines (Panayides, 2002).

\section{Value-added services (VAS)}

The competitiveness of a port depends on its ability to add value to the services it provides in the context of the overall supply chain (Robinson 2002; Carbone and De Martino 2003). Robinson (2002) suggested that ports form part of a value-driven chain and as such can add value to the goods passing through them. Carbone and De Martino (2003) pointed out that procurement and pre-assembly stages are becoming of considerable significance and may very well shape the future development of ports. The provision of value-added services involves increasing value in the context of the different operations, services and capabilities that take place in a port environment (Paixao and Marlow 2003; Song and Panayides, 2007).

\section{Inter-connecting inter-modal infrastructure (ITM)}

Ports require a high level of inter-connectivity and co-ordination within the port system. In particular, due to the inherent intermodal characteristic of container operations, an efficient coordination of multiple modes of transport at the container terminal is essential. Robinson (2002) asserted that the choice of ports is made in the context of the entire supply chain and thus competition is between alternative supply chains or routes. Thus, cargo flows will seek routes that provide the lowest cost and the ports that offer efficient Hinterland accessibility. 
Table 1

Variables of port supply chain orientation

\begin{tabular}{|c|c|}
\hline Constructs & Measurements \\
\hline $\begin{array}{c}\text { RWU } \\
\text { (Relationship } \\
\text { with users) }\end{array}$ & $\begin{array}{l}\text { RWU1: The port views us (shipping lines) as a strategic partner in mutually designing } \\
\text { the flow of goods and information. } \\
\text { RWU2: The relationship between us (shipping lines) and the port is more based on } \\
\text { mutual trust rather than on contractual obligations. } \\
\text { RWU3: We (shipping lines) work together with the port to ensure higher quality of } \\
\text { service. } \\
\text { RWU4: We (shipping lines) work together with the port to reduce costs. } \\
\text { RWU5: The port frequently measures and evaluates user satisfaction. }\end{array}$ \\
\hline $\begin{array}{c}\text { VAS } \\
\text { (Value-added } \\
\text { services) }\end{array}$ & $\begin{array}{l}\text { VAS1: The port has adequate facilities for adding value to cargoes. } \\
\text { VAS2: The port has the capacity to provide the widest possible road/rail access to } \\
\text { hinterland and foreland. } \\
\text { VAS3: The port has the capacity to launch new tailored services should the need arise. } \\
\text { VAS4: The port has a variety of services to handle the transferring of cargo from one } \\
\text { mode to another. } \\
\text { VAS5: The port has the capacity to convey cargo through the most diversified } \\
\text { routes/modes at the least possible time to end-users premises. } \\
\text { VAS6: The port has the capacity to deliver even more tailored services to different } \\
\text { market segments. }\end{array}$ \\
\hline $\begin{array}{l}\text { ITM } \\
\text { (Interconnecting } \\
\text { intermodal } \\
\text { infrastructure) }\end{array}$ & $\begin{array}{l}\text { ITM1: The port/terminal has adequate connectivity for the ship/road interface. } \\
\text { ITM2: The port/terminal has adequate operability for the ship/road interface. } \\
\text { ITM3: The port/terminal has adequate connectivity for the ship/rail interface. } \\
\text { ITM4: The port/terminal has adequate operability for the ship/rail interface. }\end{array}$ \\
\hline $\begin{array}{l}\text { CIP } \\
\text { (Channel } \\
\text { integration } \\
\text { practices) }\end{array}$ & $\begin{array}{l}\text { CIP1: The port collaborates with other channel members to plan for greater channel } \\
\text { optimization. } \\
\text { CIP2: The port seeks to identify other competing channels for cargoes that might flow } \\
\text { through the port. } \\
\text { CIP3: The port benchmarks the logistics options available for cargoes that will flow } \\
\text { through the port vis-à-vis alternative routes via competing ports. } \\
\text { CIP4: The port seeks to identify least cost options for the transport of cargoes to } \\
\text { hinterland destinations. } \\
\text { CIP5: The port constantly evaluates the performance of the transport modes available } \\
\text { for linking its terminal to its hinterland destinations. }\end{array}$ \\
\hline
\end{tabular}

Source: Panayides and Song(2006) 


\section{Channel integration practices (CIP)}

Port and terminal integration involves the extent to which the port plans and organizes activities, processes and procedures beyond its boundaries and monitors performance in such activities (Bichou and Gray, 2004). Such practices may include involvement in the introduction of new shuttle train service to the Hinterland, together with the respective national railway companies, rail operators, shipping companies and/or large shippers (Notteboom and Rodrigue, 2005). It also includes the extent to which port management collaborates with other participants of the supply chain in order to identify cost-effective and supply chain performance enhancing solutions for the goods passing through the system.

Meanwhile, the current study considers two kinds of port performance variables, i.e. customer satisfaction and port competitiveness to identify the effectiveness of port supply chain orientation. In this paper an influential linkage between customer satisfaction and port competitiveness has been suggested.

\section{Customer Satisfaction (CS)}

Customer satisfaction is the main concept of marketing considerations and it is used to assess the results and experiences of products or services purchased and used. In addition, it is the main factor for relationship orientation. The studies for customer satisfaction are mainly focused on the reuse, oral transmission effect and conversion behaviors. The existing studies have reported that customer satisfaction directly affects the degree of customer loyalty (Heskett et al., 1994; Zins, 2001; Flavian et al., 2006). The current study employs six measures to capture the degrees of satisfaction shipping lines require for their container terminals, which are shown in Table 2.

\section{Port Competitiveness (PC)}

Many previous works about port selection and competitiveness have employed a number of common factors directly related to port physical conditions and operational activities such as port location, infrastructure, superstructure, productivity, service quality, cost, marketing and hinterland accessibility (Willingale, 1982; Brudg and Daley, 1986; Tongzon, 2001, Mason, 2003; Yeo et al., 2006; and Chang et al., 2008).

However, some important strategic management literature has identified four or five performance dimensions capable of providing a firm with a competitive advantage. For instance, Hayes et al. (1988) have proposed cost, quality, dependability, flexibility and innovation as the critical components providing a firm competitive edge. Scannell et al. (2000) has noted that effective supply chain management may positively affect cost, quality, flexibility, and innovation performance. In addition, Porter (1997) has suggested that the only way to have an advantage is through innovation and improvement, involving a consistent strategic visional direction.

The current study adopts four competitiveness components reflecting cost, quality, flexibility and innovation aspects, and two market condition indices measuring port's market share and cargo 
volume trend.

Table 2

Variables of customer satisfaction and port competitiveness

\begin{tabular}{|c|c|}
\hline Constructs & Measurements \\
\hline $\begin{array}{l}\text { Customer } \\
\text { Satisfaction }\end{array}$ & $\begin{array}{l}\text { CS1: Ports/terminal's physical distribution service meets our expectation. } \\
\text { CS2: Ports/terminal's handling speed is quicker than others. } \\
\text { CS3: Ports/terminal's cargo handling charge is cheaper than others. } \\
\text { CS4: Ports/terminal corresponds rapidly to customers' requests and needs. } \\
\text { CS5: Even if price is some expensive, we (liners) will continuously use current terminal. } \\
\text { CS6: We have intention to recommend container terminals we are using to other customers. }\end{array}$ \\
\hline $\begin{array}{c}\text { Port } \\
\text { Competitiveness }\end{array}$ & $\begin{array}{l}\text { PC1: Terminal contributes to save our company's logistical cost. } \\
\text { PC2: Terminal contributes to improve our company's overall logistical service quality. } \\
\text { PC3: Terminal flexibly responses to the environmental changes and unanticipated events. } \\
\text { PC4: Terminal continuously adopts innovative technology and process. } \\
\text { PC5: Terminal that our company utilizes is expected increased market share. } \\
\text { PC6: Terminal that our company utilizes is expected increased cargo volume. }\end{array}$ \\
\hline
\end{tabular}

\section{Research methodology and findings}

\subsection{Survey procedure}

All the data for this study were collected by survey questionnaires. First, a survey instrument was developed based on the previous literature, which consists of 20 questions for port supply chain orientation, 6 questions for customer satisfaction and 6 questions for port competitiveness. Second, a pilot test was conducted to see if any important variables were excluded. Third, based on the pilot test results, the final questionnaire was established. Fourth, after collecting the survey data, a confirmatory factor analysis technique was adopted to confirm the appropriateness of factors. Finally, a structural model was developed to identify any causal relationship between port supply chain orientation and port performance.

Questionnaire instruments were distributed to shipping companies and their potential respondents were asked to evaluate most frequently called terminals in Korea and Foreign countries respectively using a 7 point Likert scale, in which 1 point means "strongly disagree" and 7 points present "strongly agree". A total of 52 valid questionnaires were collected from 21 shipping lines, among which 15 lines were domestic companies (such as Hanjin shipping, Hyundai Merchant Marine, Korea Marine Transport) and 6 companies were foreign shipping companies (such as 
MOL, WANHAI LINE, YANGMING, COSCON, APL and ZIM LINE). Around 68\% of the sample companies possess more than a 20 year history and $42 \%$ of them have more than 300 employees. In particular, 8 of the 21 responding firms were ranked among the world 20 top lines based on gross tonnage in 2007.

There were 84 evaluated container terminals, among which 52 were domestic container terminals and 32 were foreign container terminals. The most frequently used container terminals were Busan new port container terminal, Hutchison Korea terminal, Pusan East Container Terminal, Incheon container terminal, Incheon Sun-kwang container terminal, Ulsan Jeong-il container terminal in Korea, and Shanghai container terminal in China, HIT in Hong Kong, PSA in Singapore, HHLA in Germany, ECT in Netherlands, and Long beach container terminal in the United States.

\subsection{Measurement model}

In order to test the validity and reliability of the measurement model, the confirmatory factor analysis (CFA) technique was applied. Because one of the objectives of this study is to test universal application of port SCO model proposed by Panayides and Song (2006; 2007), it is sufficient to conduct a confirmatory factor analysis without an exploratory factor analysis procedure (Kim and Mueller, 1978).

Figure 1 presents the four-factor model composed of RWU (relationship with users), VAS (value added services), ITM (inter-connecting inter-modal infrastructure) and CIP (channel integration practices), in which constructs are inter-correlated as indicated by the two-headed arrows. First, the minimum requirements for model identification are satisfied by the model. All the factor loadings are greater than 0.5 except for VAS2 and their t-values are significant at 0.001 level. ${ }^{1}$ In addition, the criteria of fit indices are marginally satisfied $\left(\chi^{2} / \mathrm{df}=2.461, \mathrm{CFI}=0.803\right.$, IFI $=0.807, \mathrm{TLI}=0.772$ ). Therefore, unidimensionality and convergent validity are satisfied. Next, scale reliability is verified because the values of Cronbach's alpha for the four factors are larger than 0.8 and all the values of construct reliability are greater than 0.7 , in addition, all the values of variance extracted are greater than 0.5 except for VAS (0.452). In summary, the CFA approach has demonstrated that the measurement models marginally satisfy the validation issue.

\footnotetext{
${ }^{1}$ Loadings 0.50 or greater are considered practically significant. Loadings exceeding 0.70 are considered indicative of a well-defined structure, which is the goal of any factor analysis (Hair et al. 2006).
} 


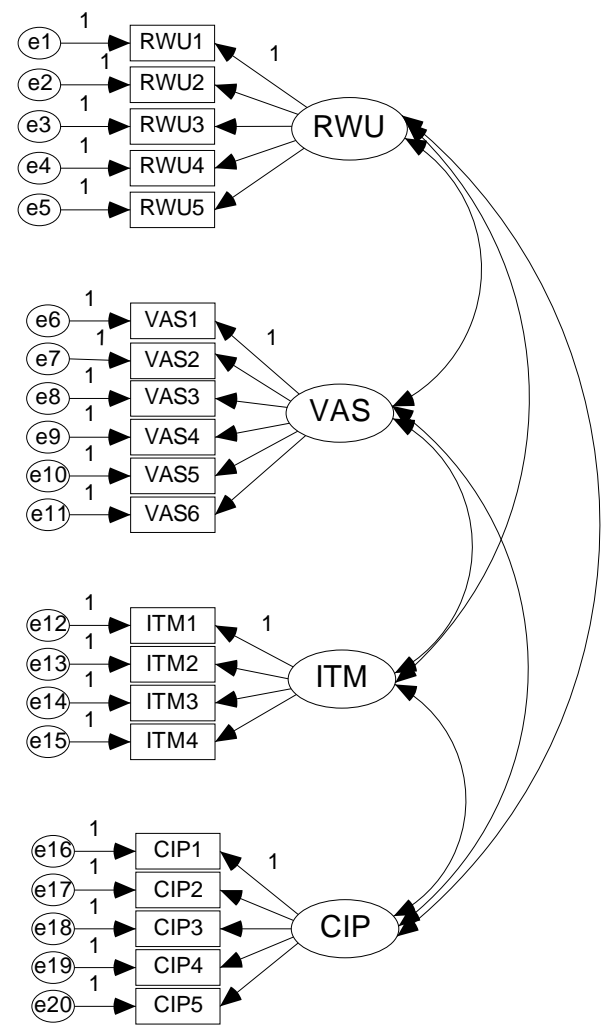

Figure 1. Measurement model for supply chain orientation

Table 3

Reliability test of latent variables

\begin{tabular}{c|c|c|c}
\hline Factors & Cronbach's Alpha & $\begin{array}{c}\text { Construct } \\
\text { Reliability }\end{array}$ & $\begin{array}{c}\text { Variance } \\
\text { Extracted }\end{array}$ \\
\hline \hline Relationship With Users (RWU) & 0.888 & 0.581 & 0.878 \\
Value Added Services (VAS) & 0.839 & 0.452 & 0.830 \\
Inter-modal Infrastructure (ITM) & 0.871 & 0.544 & 0.858 \\
Channel Integration Practices (CIP) & 0.901 & 0.643 & 0.900 \\
\hline
\end{tabular}

\subsection{Structural model}

The main objective of this study was to analyze the impact of port supply chain orientation on customer satisfaction and port competitiveness. The hypothesized relationships between the 6 constructs are shown in Figure 2 and the results are summarized in Table 4. The minimum 
requirements for model identification were satisfied and the fit indices $\left(\chi^{2} / \mathrm{df}=1.840, \mathrm{CFI}=0.797\right.$, $\mathrm{IFI}=0.802, \mathrm{TLI}=0.775)$ are marginally acceptable. Among the 9 causal paths specified in the hypothesized model, the 3 hypothesized paths (RWU $\rightarrow$ CS; VAS $\rightarrow$ PC; CS $\rightarrow$ PC) were found to be statistically significant.

Table 4

Parameter estimates of structural model

\begin{tabular}{|c|c|c|c|c|c|c|}
\hline \multicolumn{3}{|c|}{ Construct and Observed Variable } & \multicolumn{2}{|c|}{ Estimate } & \multirow{2}{*}{$\begin{array}{c}\begin{array}{c}\text { C.R. } \\
\text { (t-value) }\end{array} \\
1.973\end{array}$} & \multirow{2}{*}{$\begin{array}{c}\mathrm{p} \text {-value } \\
0.048^{*}\end{array}$} \\
\hline CS & $\leftarrow$ & RWU & 0.321 & $(0.605)$ & & \\
\hline CS & $\leftarrow$ & VAS & -0.127 & $(-0.213)$ & -0.511 & 0.609 \\
\hline CS & $\leftarrow$ & ITM & -0.203 & $(-0.394)$ & -1.162 & 0.245 \\
\hline CS & $\leftarrow$ & CIP & -0.087 & $(-0.146)$ & -0.477 & 0.633 \\
\hline PC & $\leftarrow$ & RWU & -0.064 & $(-0.086)$ & -0.468 & 0.640 \\
\hline PC & $\leftarrow$ & VAS & 0.445 & $(0.527)$ & 2.030 & $0.042 *$ \\
\hline PC & $\leftarrow$ & ITM & -0.211 & $(-0.290)$ & -1.469 & 0.142 \\
\hline PC & $\leftarrow$ & CIP & -0.147 & $(-0.175)$ & -0.999 & 0.318 \\
\hline PC & $\leftarrow$ & $\mathrm{CS}$ & 1.446 & $(1.026)$ & 5.273 & $* * *$ \\
\hline
\end{tabular}

*** Significant at $p \leq 0.001(t \geq \pm 3.29) ; * *$ Significant at $p \leq 0.01(t \geq \pm 2.57)$

* Significant at $p \leq 0.05(t \geq \pm 1.96) ; \quad$ ( ): standardized effects

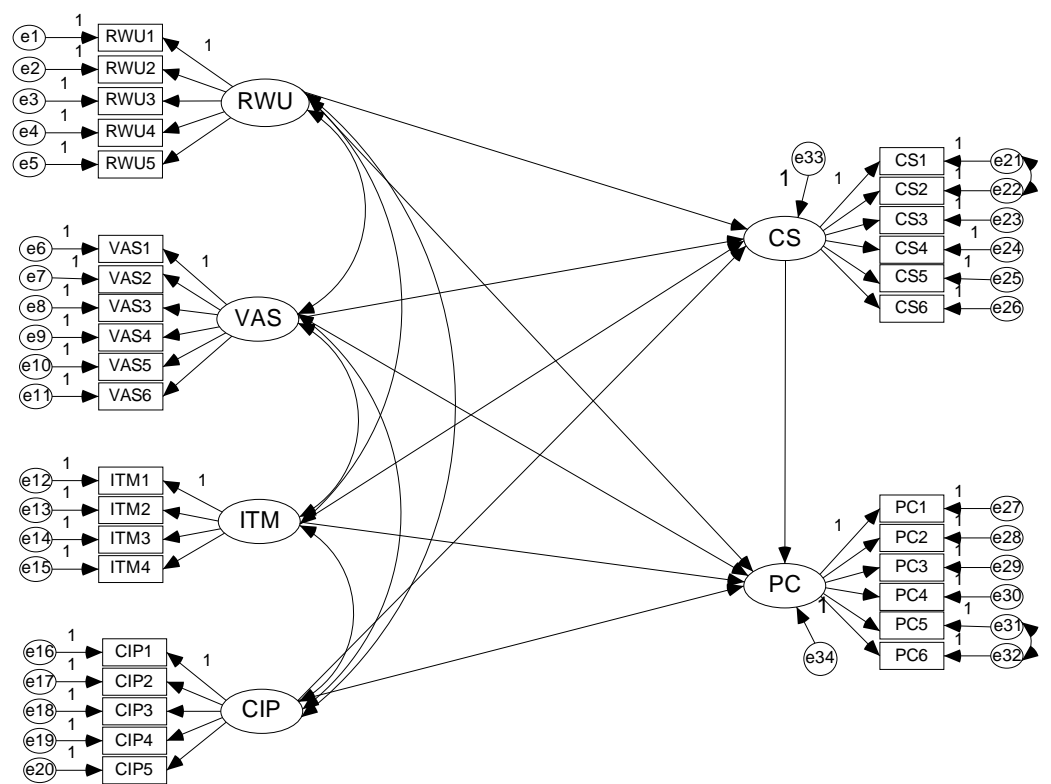

Figure 2. Full structural model 
The followings are the hypothesis test results and implications. The first hypothesis assumed that port supply chain orientation (SCO) would affect on the customer satisfaction. However, the results of the current empirical study demonstrate that this hypothesized relationship is only partially supported. Among the four constructs only RWU (relationship with users) has a significant positive influence on customer satisfaction. The significant relationship between RWU and CS is very natural because better relationships with users should result in high customer satisfaction. Based on the results, it seems difficult to argue that the port supply chain orientation does function as a critical factor affecting customer satisfaction.

The second hypothesis is also partially supported because the only one factor VAS (value added service) exerts a significant positive impact on the port competitiveness construct. However, this finding suggests that value added services could enhance the competitive advantage in container terminal management, which could provide some rationale for establishing value added strategies and supporting systems at the container ports.

Finally, the hypothesis that customer satisfaction (CS) would affect port competitiveness (PC) acquired statistical significance with standardized effect of 1.026 and a t-value of 5.273. This result has been empirically observed and supported in many research works. In addition, it should be noted that the RWU construct can exert a significant influence on port competitiveness indirectly through the customer satisfaction construct, in consequence, RWU indices should be carefully monitored and established in the real business.

\section{Conclusion}

In the current study, supply chain orientation (SCO) was found to have a limited effect on customer satisfaction and port competitiveness. The constrained effectiveness of port supply chain orientation might be caused by some implemental or practical issues such as a lack of trust, limited information sharing between supply chain members and difficulties in allocating the costs and benefits from supply chain implementation among participants. In addition, as an element of the trans-ocean supply chain, the port is not yet placed at a dominant position to harmonize, evaluate and control the entire supply chain. The leading issue in supply chain is the most fundamental and complicated problem; the port and maritime industry naturally encounter similar conditions.

However, the present study has revealed that "closer relationships with shipping lines" and "innovative value added service" could function as important components for container ports and terminals to improve their customer satisfaction and enhance competitiveness. The overall conclusion is that although the effectiveness of port supply chain orientation is not strongly confirmed in the current port management environment, the potential importance can be noticed considering the evolutionary process in the trans-ocean supply chains towards more integrated and collaborative context. 


\section{References}

Bichou, K. and Gray, R. 2004. A logistics and supply chain management approach to port performance measurement. Maritime Policy \& Management. 31 (1): 47-67.

Brudg, B. and Daley, J. 1986. Shallow-draft water transportation: marketing implications of user and carrier attribute perceptions. Transportation Journal. 24: 238-221.

Carbone, V. and De Martino, M. 2003. The changing role of ports in supply-chain management: an empirical analysis. Maritime Policy and Management. 30 (4): 305-320.

Chang, Y-T., Lee, S-Y., and Tongzon, J.L. 2008. Port selection factors by shipping lines: different perspectives between trunk liners and feeder service providers. Marine Policy. 32: 877-885.

De Souza, G.A., Beresford, A.K.C. and Pettit, S.J. 2003. Liner shipping companies and terminal operators: internationalization or globalization? Maritime Economics and Logistics. 5: 393-412.

Doney, P.M. and Cannon, J.P. 1997. An examination of the nature of trust in buyer-seller relationships. Journal of Marketing. 61: 35-51.

Flavian, C., Guinaliu, M. and Gurrea, R. 2006. The role played by perceived usability, satisfaction and consumer trust on website loyalty, Information \& Management. 43 (1): 1-14.

Hair, J., Black, B., Babin, B., Anderson, R. and Tatham, R. 2006. Multivariate data analysis (6th ed.). New York: Prentice-Hall.

Hayes, R., Wheelwright, S.C. and Clark, K.B. 1988. Dynamic manufacturing: creating the learning organization. The Free Press, New York, NY.

Heskett, J.L., Jones, T.O., Loveman, G.W., Sasser, Jr. W.E. and Schlesinger, L.A. 2004. Putting the service-profit chain to work. Harvard Business Review. 72 (2): 164-174.

Kalwani, M.U. and Narayandas, N. 1995. Long-term manufacturer-supplier relationships: do they pay? Journal of Marketing. 59 (1): 1-16.

Kim, J-O. and Mueller, C. W. 1978. Factor analysis: statistical methods and practical Issues. Sage Publications, Quantitative Applications in the Social Sciences Series. 14. CA.

Marlow, P.B. and Paixao, A.C. 2003. Measuring lean ports performance. International Journal of Transport Management. 1: 189-202.

Mason, T. 2003. Network strategy a global carrier perspective. Paper presented at the TOC 2003, Europe, Jenoa.

Mentzer, J.T., Dewitt, W., Keebler, J.S., Min, S., Nix, N.W., Smith, C. and Zacharia, Z.G. 2001. Defining supply chain management. Journal of Business Logistics. 22: 1-25.

Notteboom, T.E. and Rodrigue, J.P. 2005. Port regionalization: towards a new phase in port development. Maritime Policy \& Management. 32 (3): 297-313.

Paixao, A.C. and Marlow, P.B. 2003. Fourth generation ports - a question of agility? International Journal of Physical Distribution and Materials Management. 33 (4): 355-376.

Panayides, Ph.M. 2002. Economic organization of intermodal transport. Transport Reviews. 22 (4): 401-414. 
Panayides, Ph.M. and Song, D-W. 2006. Port supply chain orientation and performance. Paper presented at the IAME Annual Conference 2006, 12-14 July, Melbourne, Australia.

Panayides, Ph.M. and Song, D-W. 2007. Development of a measurement instrument for port supply chain orientation. Paper presented at the IAME Annual Conference 2007, 2-4 July, Athens, Greece.

Porter, M.E. 1997. Creating advantages. Executive Excellence. 14(12): 17-18.

Robinson, R. 2002. Ports as elements in value-driven chain systems: the new paradigm. Maritime Policy and Management. 25 (1): 21-40.

Scannell, T. V., Vickery, S. K. and Dröge, C. L. 2000. Upstream supply chain management and competitive performance in the automotive supply industry. Journal of Business Logistics. 21 (1): 23-48.

Song, D-W. and Panayides, P. 2007. Global supply chain and portterminal integration and competitiveness. Paper presented at the 2007 International Conference on Logistics, Shipping and Port Management, 29-30 March, Taiwan.

Tongzon, J. 2001. Efficiency measurement of selected Australian and other international ports using data envelopment analysis. Transportation Research Part A. 35: 107-122.

Willingale, M.C. 1984. Ship-operator port-routing behavior and the development process, in Hoyle, B. S. and Hilling, D. ed. Seaport systems and spatial change. New York: John Wiley \& Sons: $43-59$.

Yeo, G-T and Song, D-W. 2006. An application of the hierarchical fuzzy process to container port competition: policy and strategic implications. Transportation. 33 (4): 409-422.

Zins, A. H. 2001. Relative attitudes and commitment in consumer loyalty models, International Journal of Service Industry Management. 12 (3): 269-294. 
